\title{
Flavonoids: potent inhibitors of poliovirus RNA synthesis
}

\author{
M. E. González, ${ }^{\dagger}$ F. Martínez-Abarca and L. \\ Carrasco* \\ Centro de Biologia Molecular (CSIC-UAM), Universidad \\ Autónoma, Canto Blanco, 28049 Madrid, Spain.
}

\section{Summary}

Some naturally occurring flavonoids, such as 3-methyl quercetin and Ro-090179, show potent anti-picornavirus activity. They inhibit poliovirus replication at concentrations 100 -fold or 1000-fold lower than hydroxybenzyl-benzimidazole (HBB) and guanidine, respectively. Ro-090179 selectively blocks viral RNA synthesis in poliovirus-infected HeLa cells more strongly than 3-methyl quercetin and is therefore the most potent and selective inhibitor of poliovirus RNA synthesis described until now. In addition, Ro-090179 discriminates in its inhibition between plus- and minus-stranded RNA synthesis. Thus, analysis of the viral RNA made in poliovirus-infected cells when the compound is added late in the infection cycle, indicates that the synthesis of genomic RNA is potently blocked, whereas minus-stranded RNA synthesis is not inhibited. These findings make Ro-090179 a valuable compound for obtaining insight into the molecular mechanisms of poliovirus RNA replication.

\section{Introduction}

The search for new antiviral agents has at least two main goals. One is to provide a remedy for virus-induced diseases. The second is to provide new tools for analysing the molecular biology of animal viruses (Came and Caliguiri, 1982; Harnden, 1985). From this last viewpoint agents known to block picornavirus growth have helped to elucidate a number of aspects of their biology. Thus, several compounds selectively bind to virions in a welldefined region of their capsids (Rossmann, 1989). This binding stabilizes the viral capsid structure such that, although the viral particle still binds to the receptor and is subsequently internalized, the uncoating process is

Received 21 February, 1990; revised 28 June, 1990. *For correspondence. tPresent address: Instituto Carlos III, Majadahonda, Madrid, Spain. hampered (Alarcón et al., 1986; Diana et al., 1985; Fox et al., 1986; Ishitsuka et al., 1982a,b; Kenny et al., 1988; Ninomiya et al., 1984; Otto et al., 1985; Rosenwirth and Eggers, 1979). Other agents affect the synthesis of viral macromolecules, for instance viral translation is specifically blocked by certain inhibitors of protein synthesis that do not pass through the membranes of uninfected cells but which are taken up by infected cells (Carrasco, 1978; Carrasco et al., 1989). The selective toxicity of these agents is due to the increased permeability of membranes induced by virus infection (Carrasco, 1978; Carrasco et al., 1989). The processing of picornavirus proteins follows a complicated pattern of proteolytic cleavages of the socalled polyprotein. Inhibitors of the cleavage reactions, as amino acid analogues, zincions, or cystatin also impair the proper development of piconaviruses (Korant et al., 1980; Hutchison, 1985). Much effort has focused on developing agents that selectively inhibit viral RNA replication and elucidating their mode of action. Guanidine (Tershak et al., 1982), gliotoxin (Miller et al., 1969), hydroxybenzyl-benzimidazol (HBB) (Eggers, 1982) and several flavones are selective inhibitors of picornavirus RNA synthesis (Kaul et al., 1985; Castrillo et al., 1986; Selway, 1986). However, the precise mechanism by which these agents inhibit viral RNA replication remains unknown. Guanidine is perhaps the most thoroughly studied inhibitor of poliovirus RNA synthesis (Tershank et al., 1982). Very elegant studies have clearly identified its target on viral protein $2 \mathrm{C}$ (Pincus and Wimmer, 1986). Unfortunately, the role that protein $2 \mathrm{C}$ plays in RNA replication remains unknown (Wimmer et al., 1987). On the other hand, the concentrations of guanidine required to effectively block poliovirus RNA replication are very high $(1-3 \mathrm{~mm})$. We found that 3 -methyl quercetin (3-MQ), a natural compound isolated from Euphorbia grantii, was the most potent and selective inhibitor of poliovirus RNA replication (Castrillo et al., 1986; Castrillo and Carrasco, 1987). We report here that the flavone Ro-090179 is also a selective inhibitor of viral RNA replication. Moreover, Ro-090179 is the most active agent known to block this step in poliovirus growth. It is, at least, three times more potent than 3-MQ and 100-or 1000-fold more active than HBB or guanidine, respectively. Finally, a detailed analysis of the action of Ro-090179 on poliovirus RNA synthesis suggests that this agent specifically blocks positive-strand RNA synthesis. 
<smiles>COc1c(-c2ccc(O)c(O)c2)oc2cc(O)cc(O)c2c1=O</smiles>

3-methyl quercetin<smiles>COc1cc(O)c2c(=O)c(OC)c(-c3ccc(O)c(OC)c3)oc2c1</smiles>

Ro-090179

Fig. 1. Structural formulae of 3 methyl-quercetin and Ro-090179.

\section{Results \\ Action of several anti-picornavirus compounds on translation in poliovirus-infected cells}

Naturally occurring flavones are one of the most potent inhibitors of piconavirus replication. The structural formulae of both 3-methyl-quercetin (3-MQ) and Ro-090179 are shown in Fig. 1. In order to analyse the effect of Ro-090179 on translation in poliovirus-infected celis and to compare its activity with other picornavirus agents, different concentrations of Ro-090179 were added $1 \mathrm{~h}$ after poliovirus. Concentrations of Ro-090179 as low as $1.5 \mu \mathrm{M}$ prevented the appearance of poliovirus proteins (Fig. 2). A similar effect was found with concentrations of $3-\mathrm{MQ}$ of $5 \mu \mathrm{M}$, whereas $\mathrm{HBB}$ showed activity at concentrations above $100 \mu \mathrm{M}$. It has been reported recently that $100 \mu \mathrm{M}$ quercetin in the presence of $100 \mu \mathrm{M}$ L-ascorbate inhibits poliovirus growth, as measured with the plaque reduction assay (Vrijsen et al., 1988). It was speculated that the antiviral mechanism of action of quercetin, combined with L-ascorbate, would be similar to 3-MQ. This does not seem to be the case, since the reduction of poliovirus plaque formation by these two agents is most probably due to their cellular toxicity at those high concentrations. In our hands $100 \mu \mathrm{m}$ quercetin, plus $100 \mu \mathrm{M}$ ascorbate, inhibited protein synthesis in uninfected HeLa cells by $80 \%$, whereas no such effect was observed with $50 \mu \mathrm{M}$ $3-\mathrm{MQ}$ or $30 \mu \mathrm{M}$ Ro-090179. The results show in Fig. 2 that the effect of quercetin plus ascorbic acid on protein synthesis in poliovirus-infected cells differs from the action of Ro-090179, or 3-MQ. It must be kept in mind that 3-MQ does not prevent the shut-off of host translation induced by poliovirus, hence less cellular proteins are made in the infected cells, even in the presence of this agent (Castrillo et al., 1986).

\section{Effects of Ro-090179 on poliovirus RNA synthesis}

Ro-090179 is a natural compound isolated from a Chinese medical herb, Agastache rugosa. Studies on its mode of action on rhinovirus and coxsackie virus $\mathrm{B} 1$ indicated that it blocked an early step located after viral uncoating, but prior to the initiation of viral RNA synthesis (Ishisuka et al., $1982 a, b)$. The possibility that this agent acts on a cellular function required for viral replication has also been put forward (Ninomiya et al., 1985). Figure 3 shows that Ro-090179 blocks the incorporation of ${ }^{3} \mathrm{H}$ ]uridine in poliovirus-infected cells very soon after its addition, even $4 \mathrm{~h}$ after infection, once the bulk of viral RNA synthesis has commenced. Curiously enough, when Ro-090179 was added when viral RNA was declining, the incorporation of $\left[{ }^{3} \mathrm{H}\right]$ uridine was prolonged. This experiment was repeated several times with a similar result. At present we have no explanation for this finding. One possibility is that a viral RNA species whose synthesis is not inhibited by Ro090179 accumulates under these conditions (see below).

To analyse the formation of poliovirus RNA in the presence of these inhibitors, RNA was extracted from infected cells at $5 \mathrm{~h}$ post-infection (p.i.) and analysed by dot-hybridization using a poliovirus-specific DNA probe. Figure 4 shows that Ro-090179, 3-MQ, guanidine and HBB powerfully inhibited the appearance of poliovirus RNA when added $1 \mathrm{~h}$ p.i. Quercetin alone decreased the replication of poliovirus RNA, perhaps as a consequence of its toxic effects on cells. The combination of quercetin and ascorbic acid does not enhance the inhibition of poliovirus RNA synthesis, suggesting once again that the action of these two agents differs from the activity of 3-MQ or Ro-090179. However, the addition of quercetin plus ascorbic acid blocks the transport of [ $\left.{ }^{3} \mathrm{H}\right]$ uridine to these cells (results not shown) and therefore this assay does not seem suitable for studies on the action of quercetin and ascorbic acid on [3 H]uridine incorporation.

\section{Effects of flavonoids on the synthesis of poliovirus plus- or minus-stranded RNA}

The elongation of poliovirus plus- or minus-stranded RNA is accomplished by the virus-coded replicase (protein

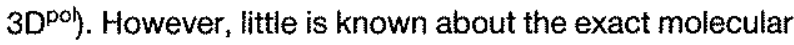
mechanism that initiates synthesis of these RNA species. A role of the viral protein VPg as a primer of plus-stranded RNA synthesis has been recognized (Wimmer et al., 1987). 


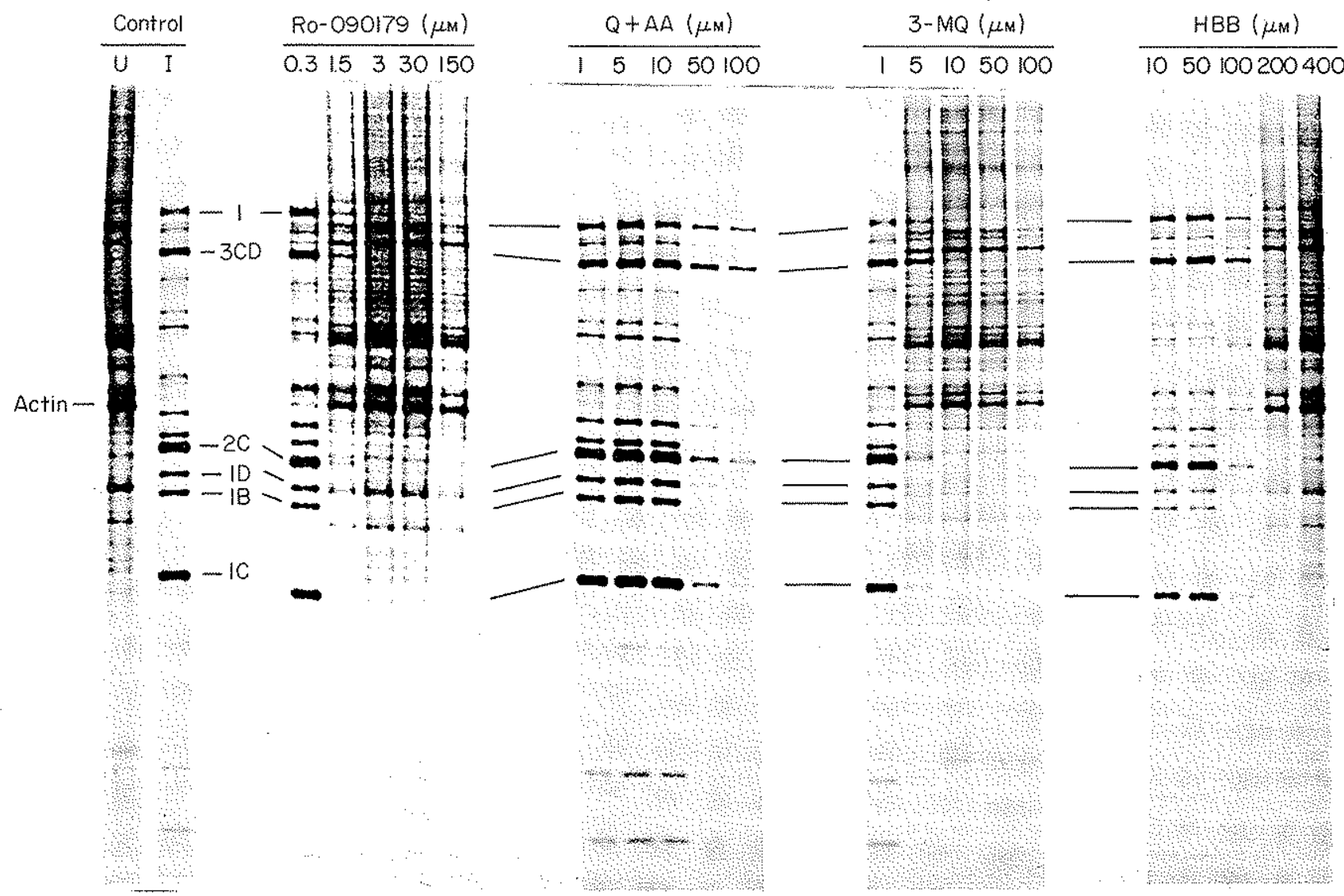

Fig. 2. Dose-dependent effect of tlavonoids on poliovirus protein synthesis. Hel.a cells were infected with poliovirus at a multiplicity of 20 p.f.u. cell ${ }^{-1}$. At on of infection, cell monolayers were treated with the indicated concentration of compounds. At 5 h p.i. cells were incubated with [ ${ }^{35}$ S]methionine and proteins were analysed in polyacrylamide gels as described in the Materiais and Experimental procedures. Some of the viral proteins are indicated. $U$, uninfected control cells; $I$, infected control cells; $Q+A A$, cell monolayers treated with $100 \mu \mathrm{M}$ ascorbic acid and the indicated concentration of quercetin.

However, it is still not clear whether the initiation of minus-stranded synthesis follows a mechanism identical to that of genomic RNA. None of the inhibitors of poliovirus RNA synthesis is known to be selective for plus- or minus-stranded RNA synthesis, and a specific inhibitor would be of great value. Therefore, we tested the effect of flavones on the synthesis of poliovirus genomic RNA, or minus-stranded RNA. For this purpose Ro-090179 was added at different times p.i. and RNA was extracted eight hours p.i. As a control RNA was extracted from infected cells, in the absence of inhibitor, at different times p.i., in order to know the kinetics of plus- or minus-stranded RNA synthesis. The amount of RNA made in control infected cells from 0 time until the $8 \mathrm{~h} \mathrm{p.i.} \mathrm{is} \mathrm{indicated} \mathrm{as} \mathrm{a} \mathrm{control.}$ Dot-hybridization was performed with poliovirus plus- or minus-stranded probes derived by in vitro transcription of a poliovirus genome segment flanked by $\mathrm{T} 7$ and $\mathrm{T} 3$ promoters in a Bluescript plasmid. Figure 5 shows that Ro-090179 selectively inhibits the synthesis of plusstranded RNA, as measured by dot-blot hybridization. Figure $5 b$ shows the quantitative estimation in a densi- tometer of the dot-blots shown in Fig. 5a. In order to see the inhibition caused by Ro-090179 on RNA synthesis when the compound was added at 0,2 or 4 h p.i. (+ labels) until the $8 \mathrm{~h}$ after infection, we first sustracted the amount of RNA already present at that time $(0,2,4$ labels $)$ and then compared that figure with the total amount of viral RNA present $8 \mathrm{~h}$ after infection (labelled as $\mathrm{C}$ ). Almost complete elimination of genomic RNA synthesis was observed when the inhibitor was added at 0,2 , or $4 \mathrm{~h}$ p.i., while under these conditions minus-stranded RNA synthesis was only inhibited when the compound was added at 0 or $2 \mathrm{~h}$ p.i., perhaps as a consequence of +RNA inhibition, whereas the synthesis of - RNA was even stimulated when the compound was added at $4 \mathrm{~h}$ p.i.

To extend this analysis of the selective effect of Ro090179 on poliovirus RNA synthesis, the RNA produced was analysed by Northern hybridization. Figure 6 shows that, in agreement with the results of Fig. 5, there is a strong blockade of poliovirus plus-stranded RNA synthesis by Ro-090179 when added $4 \mathrm{~h}$ p.l., whereas no inhibition on poliovirus minus-stranded RNA synthesis is 


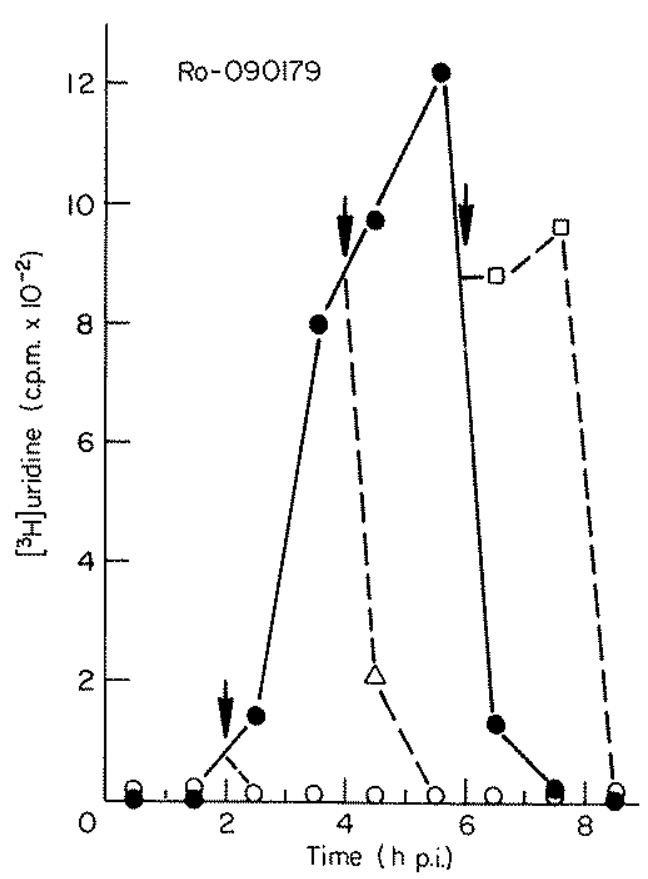

Fig. 3. Effect of Ro-090179 on the time-course of poliovirus RNA synthesis. HeLa cell monolayers were treated with $5 \mu \mathrm{g} \mathrm{ml}^{-1}$ actinomycin D to block cellular RNA synthesis. Ro-090179 (3 HM) was added at 0, 2, 4 and $6 \mathrm{~h}$ p.i. (arrows) and kept until the ninth hour and the time course of RNA synthesis was followed by measuring $\left.{ }^{3} \mathrm{H}\right]$ uridine incorporation into TCA precipitable material, as described in the Materiais and Experimental procedures. For this purpose $[3$ Hiluridine was added every hour after infection and incubated during $1 \mathrm{hr}$. The value obtained was plotted in the middle of each time point. (O) Untreated poliovirus-infected celis; $(0, \Delta$,$) poliovirus minfected cells treated with$ $3 \mu \mathrm{M}$ Ro-090179.

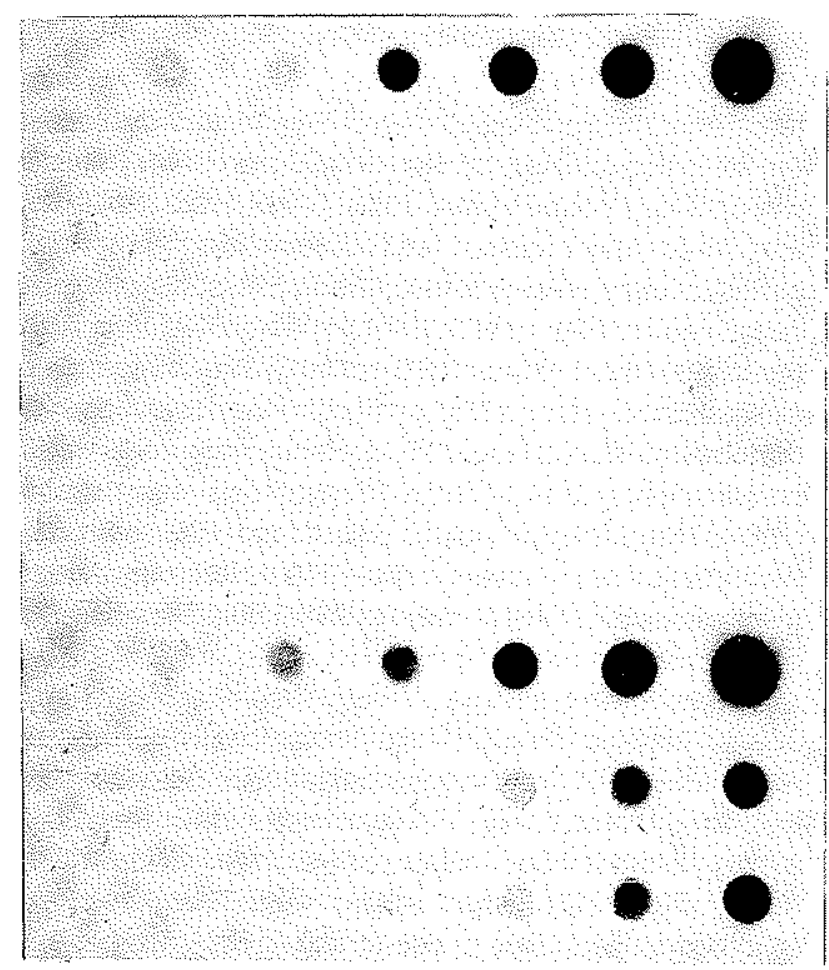

detected. Our results clearly suggest that Ro-090179 is a selective inhibitor of the synthesis of poliovirus genomic RNA. To our knowledge, this represents the first instance that such a selective inhibitor is described.

\section{Discussion}

Flavonoids are ubiquitous compounds in the plant kingdom (Harborne, 1988). The search for antiviral agents in plant extracts led to the discovery of 3-methyl quercetin (3-MQ) from the African medicinal plant Euphobia grantii (Van Hoof et al., 1984) and Ro-090179 from the Chinese medicinal herb Agastache rugosa (Ishitsuka et al., 1982b). Analyses of the mode of action of 3-MQ indicated that it was a selective inhibitor of poliovirus RNA synthesis. At a concentration of $5 \mu \mathrm{g} \mathrm{ml}{ }^{-1} 3-\mathrm{MQ}$ inhibited [ $\left.{ }^{3} \mathrm{H}\right]$ uridine incorporation in poliovirus-infected cells by $90 \%$, whereas at $20 \mu \mathrm{g} \mathrm{mi}^{-1} 3-\mathrm{MQ}$ had no effect on cellular transcription (Castrillo et al., 1986). Analysis of the viral RNA synthesized in the presence of this flavone showed that production of single-stranded RNA was totally blocked, whereas the synthesis of double-stranded RNA was detected. We interpreted these results as evidence that $3-\mathrm{MQ}$ was a selective inhibitor and preferentially inhibited synthesis of plus-stranded, as opposed to minus-stranded, RNA. López-Plla et al. (1989) found that addition of this flavone from the very beginning of poliovirus infection, i.e. together with the virus inoculum, prevented the synthesis

Control

Guanidine

HBB

3-MQ

Ro-090179

Ascorbic acid

Quercetin

Quercetin +

ascorbic acid

Ro

Ascorbic acid
Fig. 4. Effect of several compounds on viral RNA content of poliovirus-infected cells. HeLa cells were infected with 5 p.f.u. cell ${ }^{-1}$ of poliovirus and treated with the indicated concentration of compounds from the beginning of infection and twofold serial dilutions from $2.5 \mu \mathrm{g}$ of PNA were dotted on nitrocellulose paper and hybridized with a DNA probe specific for poliovirus. 
(a)

h p.i. Ro addition Ro added

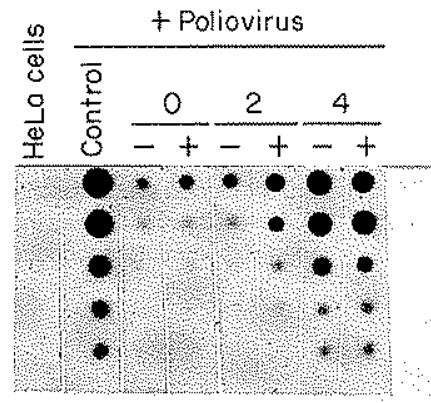

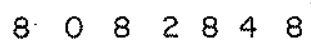

RNA extracted ot hpi.

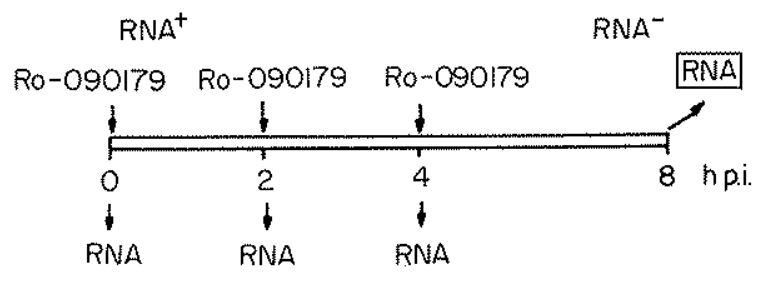

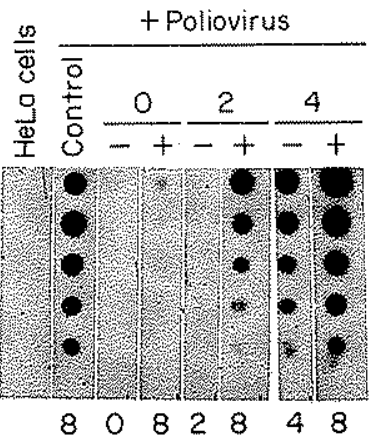

RNA

(b)

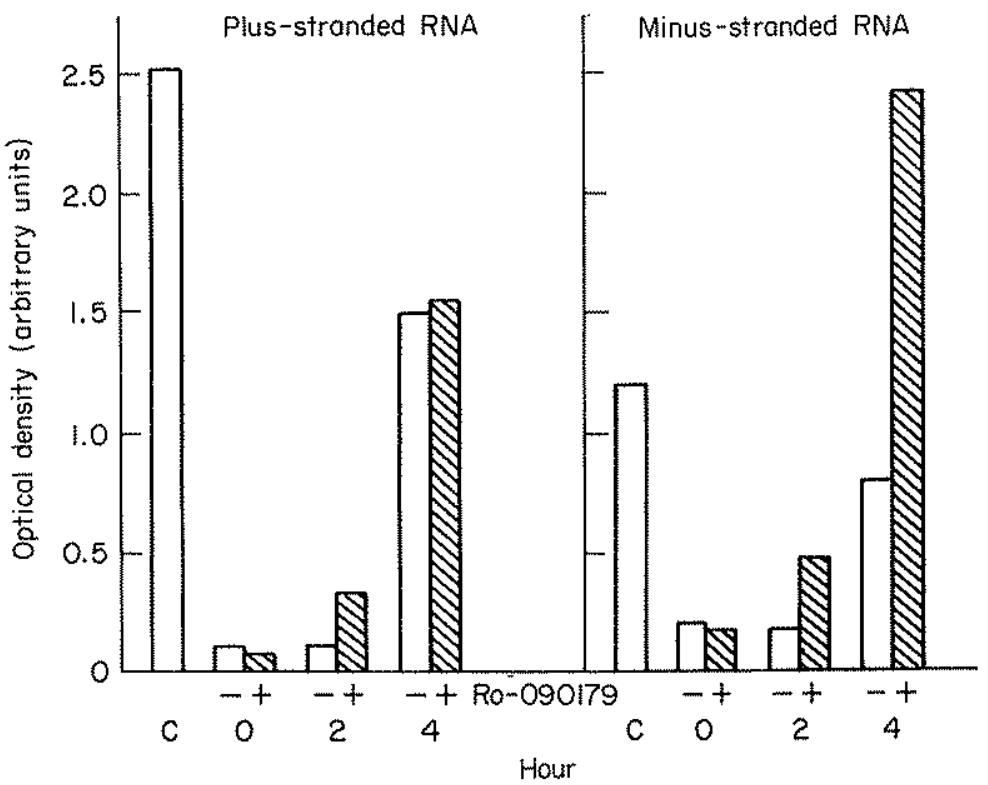

Fig. 5. Dot blot analysis of poliovirus RNA levels. (a) Total RNA was extracted from infected cultures at 0, 2, $4 \mathrm{~h} \mathrm{p.j.}$. and $8 \mathrm{~h} \mathrm{p.j.}$ in the absence of inhibitor (control). At the times indicated in (b), Ro-090179 was added and kept until the eighth hour, when RNA was extracted from all the samples containing the inhibitor. Twotold serial dilutions of $2.5 \mu \mathrm{g}$ RNA were subjected to hybridization to + strand-specific (left) or strand-specific (right) poliovirus RNA probes. A blot exposure of $5 \mathrm{~h}$ was used in the case of the + strand-specific probe, whereas a $24 \mathrm{~h}$ exposure was used for - strand-specific probes. The quantification of the dots (b) was made using a 3000 A computing densitometer (Molecular Dinamics).

of both plus- and minus-stranded poliovirus RNA. Our present results obtained with Ro-090179 indicate that the findings of López-Pila et al. (1989), although correct, must be expanded in order to reach a correct interpretation of the action of flavones on poliovirus RNA synthesis. Thus, 3-MQ, similar to Ro-090179, certainly blocks the synthesis of both plus- and minus-stranded RNA when added from the very beginning of infection, because there is not enough genomic RNA to serve as template to give rise to significant amounts of negative-stranded RNA that could be detected by hybridization (Castrillo and Carrasco, 1987; López-Pila et al., 1989). Therefore, in order to test if those flavones are selective, they must be added later during infection, when sufficient amounts of plus-' and minus-stranded RNA are being made. The results of addition of Ro-090179 late in infection on viral RNA synthesis clearly suggest a preferential inhibition of poliovirus genomic RNA.

$A$ detailed understanding of the molecular mode of action of both 3-MQ and Ro-090179 is still lacking, because we do not yet know which viral protein is the target of their action. It is also unknown if the initiation, or the elongation, or both steps of viral RNA synthesis are blocked by these compounds. Experiments are under way in our laboratory to distinguish between these different possibilities. 


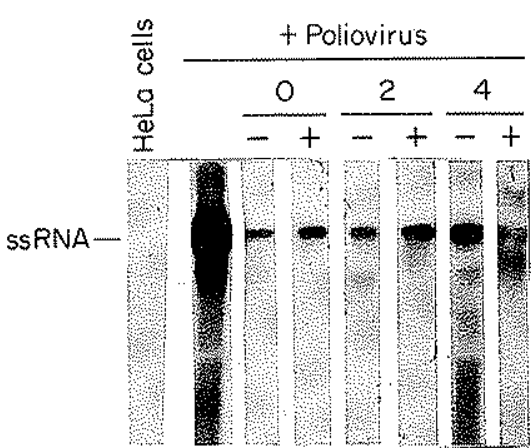

RNA+

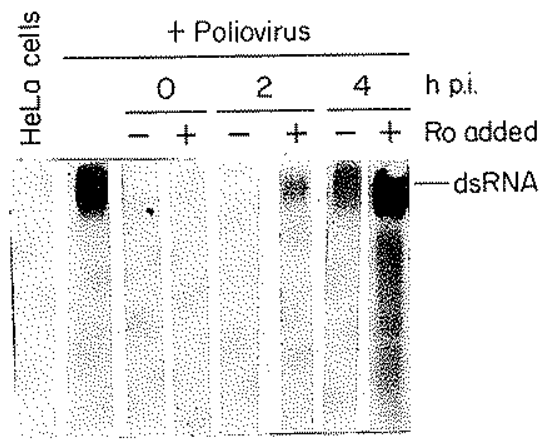

RNA-
Fig. 6. Northern blot analysis of poliovirus RNA levels. The RNA extracted as indicated in Fig. 5 was analysed by agarose gel electrophoresis and Northern blotting. The same blot was hybridized to positive-stranded and negative-stranded potiovirus riboprobes obtained from a poliovirus cDNA cloned in a Bluescript plasmid, flanked by $T 7$ and T3 promoters as indicated in the Materials and Experimental procedures.

\section{Materials and Experimental procedures Cell and virus growth}

HeLa cells were grown in 100-mm plastic dishes (Nunc, Roskilde, Denmark) in Dubecco's modified Eagle's medium, containing $10 \%$ newborn calf serum (Gibco, Grand Island, NY). Poliovirus type 1 (Mahoney strain) (ATCC) was grown in HeLa cells. The procedures for cell culture and virus titration were as described elsewhere (González et al., 1987).

\section{Compounds}

$4^{\prime}$-5-dihydroxy-3-3',7-trimethoxyflavone (Ro-090179) was kindly provided by Dr Ishitsuka and Dr Yokose, Nippon Roche Research Center (Kamakura, Japan). 3'methyl quercetin (3-MQ) was a generous gift from D. Vanden Berghe (University of Antwerp, Belgium). 2-( $\beta$-hydroxybenzyl) benzimidazole (HBB) was kindly given by E. Wimmer (University of New York, NY). Quercetin, ascorbic acid and guanidine were purchased from Sigma Chemical Co., St Louis, MO.

\section{DNA probe}

The full length poliovirus genome DNA probe was obtained by EcoRl digestion of the pSVO-poliovirus vector (Pincus and Wimmer, 1986). The restriction fragment was recovered from a low melting agarose gel and labelled with [ $\alpha{ }^{32}$ P]dATP $(400$ $\mathrm{Ci} / \mathrm{mmol}$; The Radiochemical Centre, Amersham, Bucks, UK) by nick-translation.

\section{RNA probe}

The poliovirus strand-specific RA probe was generated by in vitro transcription of a fragment of poliovirus CDNA, between nucleotides 2099 and 77 (New England Biolabs, USA) and $T_{3}$ RNA polymerases (Stratagene, USA). We obtained RNA probes (ATCC) specific to the viral minus and plus strand, respectively. The probes were labelled with $\left[\alpha^{32}\right.$ PJCTP $(400 \mathrm{Ci} / \mathrm{mmol}$; The Radiochemical Centre) (Melton et al., 1984).

\section{Virus infection of cell monolayers}

HeLa cells were infected with poliovirus $(-1$ h) in Dulbecco's modified Eagle medium supplemented with $2 \%$ newborn calf serum. After incubation at $37^{\circ} \mathrm{C}$, for $1 \mathrm{~h}$, unattached virus was removed and fresh medium was added (Oh).

\section{Polyacrylamide gel analysis of proteins}

At the time indicated, cells were incubated in methionine-free medium in the presence of $5 \mu \mathrm{Ci}$ per $\mathrm{ml}$ of $\left[{ }^{35} \mathrm{~S}\right]$ methionine ( 1100 $\mathrm{Ci} / \mathrm{mmol}$; The Radiochemical Centre). One hour later the radioactive medium was removed, the cell monolayer was washed with phosphate-buffered saline and cells were collected in $200 \mu \mathrm{s}$ buffer containing $62 \mathrm{~mm}$ Tris- $\mathrm{HCl}(\mathrm{pH} 6.8), 2 \% \mathrm{SDS}, 0.1 \mathrm{M}$ dithiothreitol, $17 \%$ glycerol and $0.0024 \%$ bromophenol blue. Each sample was sonicated to reduce viscosity and heated at $90^{\circ} \mathrm{C}$ for $5 \mathrm{~min}$. Five microlitres were applied to a $15 \%$ polyacrylamide gel and run overnight at $100 \mathrm{v}$. Fluorography of the gel was carried out with 2,5 diphenyloxazole/dimethyl sulphoxide $(20 \% \mathrm{w} / \mathrm{v})$. The dried gels were exposed using RP-X1-ray films (Alarcón et al., 1988).

\section{RNA blot analysis of poliovirus}

HeLa cells were grown in $60-\mathrm{mm}$ dishes and infected with poliovirus. At the indicated times after infection the cells were lysed in a buffer containing $10 \mathrm{~mm}$ Tris-hydrochloride $(\mathrm{pH} 7.8)$, $1 \mathrm{~mm}$ EDTA, $150 \mathrm{~mm} \mathrm{NaCl}$ and $0.65 \%$ Nonidet $P-40$. Cell extracts were treated with proteinase $K$ and DNase 1. Total RNA was extracted with phenol and precipitated with ethanol (Favaloro et al., 1980). Dot and Northern blot analysis with a radiolabeled probe was performed as described (Thomas, 1983). The quantification of dots was done with a $3000 \mathrm{~A}$ computing densitometer (Molecular Dynamics, CA, USA).

\section{Measurement of nucleoside incorporation into RNA}

Cell monolayers were incubated every hour post-infection in the presence of $20 \mu \mathrm{Ci}$ per $\mathrm{ml}$ of $\left[{ }^{3} \mathrm{H}\right]$ uridine $(40 \mathrm{Ci} / \mathrm{mmol}$; The Radiochemical Centre) for $1 \mathrm{~h}$. Then, cell monolayers were washed with phosphate-buffered saline and TCA precipitated. The TCA was removed and the precipitated cell monolayer was thoroughly washed with ethanol. Afterwards, it was dried under an infrared lamp and dissolved in $250 \mu$ of $0.02 \mathrm{~N} \mathrm{NaOH}$ plus $0.1 \%$ SDS. An $0.1-\mathrm{ml}$ aliquot was taken and suspended in scintillation liquid to estimate radioactivity. 


\section{Acknowledgements}

MEG and FMA are holders of a FPI fellowship. Fundación Ramón Areces and CICYT (B1088-0233) are acknowledged for financial support. The technical assistance of Ms M.A. Chorro is gratefully acknowledged.

\section{References}

Alarcón, B., Zerial, A., Dupiol, C., and Carrasco, L. (1986) Antirhinovirus compound $44081 \mathrm{RP}$ inhibits virus uncoating. Antimicrob Agents Chemother 30: 31-34.

Alarcón, B., González, M.E., Carrasco, L. Méndez-Castrillón, P.P., Garcia-López, M.T., and de las Heras, F.G. (1988) Mode of action of a new type of UDP-glucose analog against herpesvirus replication. Antimicrob Agents Chemother 32: $1257-1261$.

Came, P.E., and Caliguiri, L.A. (1982) Chemotherapy of Viral Infections. Springer-Verlag, Berlin.

Carrasco, L. (1978) Membrane leakiness after viral infection and new approach to the development of antiviral agents. Nature 272: 694-699.

Carrasco, L., Otero, M.J., and Castrillo, J.L. (1989) Modifications of membrane permeability by virus infections. Pharmacol Ther 40: $171-212$.

Castrillo, J.L., and Carrasco, L. (1987) Action of 3-methyl-quercetin on poliovirus RNA replication. $J$ Virol $61: 3319-3321$.

Castrillo, J.L., Vanden Berghe, D., and Carrasco, L. (1986) 3-methyl-quercetin is a potent and selective inhibitor of poliovirus RNA synthesis. Virology 152: 219-227.

Diana, G.D., Otto, M.J., and McKinlay, M.A. (1985) Inhibitors of picornavirus uncoating as antiviral agents. Pharmacol Ther 29: 287-297.

Eggers, H.J. (1982) Benzimidazoles. In: Chemotherapy of Viral Infections (eds P.E. Came, and L.A. Caliguiri), pp. 377-48. Springer-Verlag, Berlin.

Favaloro, J., Trisman, R., and Kamen, R. (1980) Transcription maps of polyoma virus-specific RNA analysis by two-dimen. sional nuclease $\mathrm{S} 1$ gel mapping. Methods Enzymol 65: 718749.

Fox, M.P., Otto, M.J., and McKinlay, M.A. (1986) Prevention of rhinovirus and poliovirus uncoating by WIN 51711 a new antiviral drug. Antimicrob Agents Chemother 30: 110m116.

González, M.E., Alarcón, B., and Carrasco, L. (1987) Polysaccharides as antiviral agents: Antiviral activity of carrageenan. Antimicrob Agents Chemother 31: 1388-1393.

Harborne, J.B. (1988) The Flavonoids. Champman and Hall, London.

Harnden, M.R. (1985) Approaches to Antiviral Agents. McMillan, London.

Hutchison, D.W. (1985) Metal chelators as potential agents. Antiviral Res 5: 193-205.

Ishitsuka, H., Ninomiya, Y.T., Onsawa, C., Fuji, M., and Suhara, Y. (1982a) Direct and specific inactivation of rhinovirus by chalcone RO-09-0410. Antimicrob Agents Chemother 22: 617-621.

Ishitsuka, H., Ohsawa, C., Oniwa, T., Umeda, I., and Suhara, Y. (1982b) Antipicornavirus flavone RO-09-0179. Antimicrob Agents Chemother 22: 611-616.
Kaul, T.N., Middleton, E., and Ogra, L. (1985) Antiviral effect of flavonoids on human viruses. $J$ Med Virol 15: 71-79.

Kenny, M.T., Torney, H.L., and Dulworth, J.K. (1988) Mechanism of action of the antiviral compound MDL 20,610. Antiviral Res 9 : 249-261,

Korant, B.D., Chow, N.L., Lively, M.O., and Powers, P.C. (1980) Proteolytic events in replication of animal viruses. Ann NY Acad Sci 343: 304-318.

López-Pila, J.M., Kopecka, H., and Vanden Berghe, D. (1989) Lack of evidence for strand-specific inhibition of poliovirus RNA synthesis by 3-methyl quercetin. Antiviral Res 11: 47-54.

Melton, D.A., Krieg, P.A., Rebagliati, M.R., Maniatis, T., Zinn, K., and Green, M.R. (1984) Efficient in vitro synthesis of biologically active RNA and RNA hybridization probes from plasmids containing a bacteriophage SP6 promoter. Nucl Acids Res 12: 7035-7056.

Miler, P.A., Milstrey, K.P., and Trown, P.W. (1969) Specific inhibition of viral ribonucleic acid replication by gliotoxin. Science 159: 431-432.

Ninomiya, Y., Ohsawa, C., Aoyama, M., Umeda, I., Suhara, Y., and Ishitsuka, H. (1984) Antivirus agent RO 09-0410 binds to minovirus specifically and stabilizes the virus conformation. Virology 134: 269-276.

Ninomiya, Y., Ooyama, M., Umeda, I., Suhara, Y., and Ishitsuka, $H .(1985)$ Comparative studies on the modes of action of the antirhinovirus agents RO 09-0410, RO-09-0179, RM!$15,731,4^{\prime}, 6$-dichloroflavan and enviroxime. Antimicrob Agents Chemother 27: 595-599.

Otto, M.J., Fox, M.P., Fancher, M.J., Kuhrt, M.F., Diana, G.D., and McKinlay, M.A. (1985) in vitro activity of WIN 51711, a new broad-spectrum antipicornavirus drug. Antimicrob Agents Chemother 27: 883-886.

Pincus, S.E., and Wimmer, E. (1986) Production of guanidine resistant and dependent poliovirus mutants from cloned cDNA: mutation in polypeptide $2 \mathrm{C}$ are directly responsible for altered guanidine sensitivity. $J$ Virol 60: 793 796.

Rosenwirth, B., and Eggers, H. (1979) Early processes of echovirus 12 infection: elution, penetration and uncoating under the influence of rhodanine. Virology 97: 2412-255.

Rossmann, M.G. (1989) The structure of antiviral agents that inhibit uncoating when complexed with viral capsids. Antiviral Res 11: 3-14.

Seiway, J.W.T. (1986) Antiviral activity of flavones and flavans. In: Plant Flavonoids in Biology and Medicine: Biochemical, Pharmacological and Structure Activity Relationships, pp. 521-536. Alan R. Liss, Inc., NY.

Tershak, D.R., Yin, F.H., and Korant, B.D. (1982) Guanidine. In: Chemotherapy of Viral infections (eds P.E. Came, and L.A. Caliguiri), pp. 343-376. Springer-Verlag, Berlin.

Thomas, S.P. (1983) Hybridization of denatured RNA transferred or dotted to nitrocellulose paper. Methods Enzymol 100: 255-266.

Van Hoof, L., Vanden Berghe, D., Hatfield, G.M., and Vientinck, A.J. (1984) Plant antiviral agents. V. 3-methoxyflavones as potent inhibitors of viral-induced block of cell synthesis. Planta Med 6: 513-517.

Vrijsen, R., Everaert, L., and Boeye, A. (1988) Anitviral activity of flavones and potentiation by Ascorbate. $J$ Gen Virol 69: 1749-1751.

Wimmer, E., Kuhn, R., Pincus, S., Yong, C.F., Toyoda, H., Nicklin, M.J.H., and Takeda, N. (1987) Molecular events lending to picornavirus genome replication. J Cell Sci Suppl. 7: 251-276. 